\title{
Karakteristik kerusakan tulang alveolar pada penderita periodontitis kronis dan agresif dengan pencitraan cone beam computed tomography
}

\author{
Hentartika Desyaningrum ${ }^{1}$, Lusi Epsilawati ${ }^{1 *}$, Yanti Rusyanti $^{2}$ \\ 1Departemen Radiologi Kedokteran Gigi, Fakultas Kedokteran Gigi, Universitas Padjadjaran, Indonesia \\ ${ }^{2}$ Departemen Periodonti, Fakultas Kedokteran Gigi, Universitas Padjadjaran, Indonesia \\ *Korespondensi: lusi.epsilawati@fkg.unpad.ac.id
}

\begin{abstract}
ABSTRAK
Pendahuluan: Resorpsitulang alveolar merupakan suatu proses kompleks yang secara morfologis berhubungan dengan luasnya bentuk permukaan tulang yang terkikis (Howship's lacunae) serta adanya sel berinti banyak atau osteoklas. Resorpsi tulang alveolar dapat terjadi pada periodontitis agresif dan kronis. Secara radiografis terlihat pola kerusakan tulang yang berbeda, pola horizontal pada periodontitis kronis dan pola vertikal atau pola arch shaped yang khas pada periodontitis agresif. Tujuan penelitian untuk mengetahui karakteristik kerusakan tulang alveolar pada penderita periodontitis agresif dengan pencitraan Cone Beam Computed Tomography Three Dimensional (CBCT 3D). Metode: Jenis penelitian deskriptif, Sampel penelitian sebanyak 161 sampel pencitraan CBCT yang diambil dari 6 pasien periodontitis agresif sebagai subjek penelitian dan 107 sampel pencitraan CBCT yang diambil dari 4 pasien periodontitis kronis sebagai subjek kontrol, yang diperoleh dengan teknik pengambilan sampel purposive sampling. Hasil: Potongan coronal dan sagital menunjukkan bahwa pada periodontitis, kerusakan resorpsi tulang alveolar berjumlah $69 \%$ dan pada periodontitis agresif berbentuk arch shaped berjumlah 48,9\%. Potongan sagital pada periodontitis kronis bentuk horizontal 65\% dan periodontitis arch shaped $48,9 \%$. Simpulan: Karakteristik kerusakan tulang alveolar melalui CBCT, pada periodontitis kronis berupa pola resorpsi harizontal, sedangkan pada periodontitis agresif didominasi oleh kerusakan tulang berbentuk arch shaped.
\end{abstract}

Kata Kunci: Kerusakan tulang alveolar, Periodontitis kronis, Periodontitis agresif, Cone Beam Computed Tomography

\section{Characteristics of alveolar bone damage in patients with chronic and aggressive periodontitis with Cone Beam Computed Tomography imaging}

\section{ABSTRACT}

Introduction: Resorption of alveolar bone is a complex process that is morphologically related to the extent of eroded bone surface (Howship's lacunae) and the presence of many nucleated cells or osteoclasts. Resorption of alveolar bone can occur in aggressive and chronic periodontitis. Radiographically different bone damage patterns are seen, horizontal patterns in chronic periodontitis and vertical patterns or arch shaped patterns that are typical of aggressive periodontitis. The aim of the study was to determine the characteristics of alveolar bone damage in patients with aggressive periodontitis by imaging three-dimensional Cone Beam Computed Tomography (CBCT 3D). Methods: Type of descriptive study, a sample of 161 CBCT imaging samples taken from 6 aggressive periodontitis patients as research subjects and 107 CBCT imaging samples taken from 4 chronic periodontitis patients as control subjects, obtained by purposive sampling sampling technique. Results: Coronal and sagittal fragments showed that in periodontitis, damage to alveolar bone resorption was $69 \%$ and in arch shaped aggressive periodontitis was $48.9 \%$. Sagittal cuts in horizontal form of chronic periodontitis $65 \%$ and arch shaped periodontitis 48.9\%. Conclusion: Characteristics of alveolar bone damage through CBCT, in chronic periodontitis in the form of a day-to-day resorption pattern, whereas in aggressive periodontitis it is dominated by arch shaped bone damage.

Keywords: Kerusakan tulang alveolar, Periodontitis kronis, Periodontitis agresif, Cone Beam Computed Tomography 


\section{PENDAHULUAN}

Periodontitiskronis adalah peradangan padajaringan periodontal yang disebabkan oleh akumulasi plakgigi. Periodontitis awalnya dimulai sebagai gingivitis yang berkembang menjadi periodontitis. ${ }^{1}$ Periodontitis kronis adalah penyakit yang berkembang tanpa rasa sakit, terdiri dari ringan sampai berat. ${ }^{1}$ Di AS sekitar $35 \%$ orang dewasa berusia 30-90 tahun menderita penyakit ini. ${ }^{1}$ Periodontitis ditandain dengan adanya kehilangan tulang alveolar, dan perlekatan membran periodontal serta terbentuknya pocket. Insidensi kerusakan periodontal meningkat seiring bertambahnya usia, tingkat tertinggi terjadi antara 50-60 tahun, resesi gingiva pada usia sebelum 40-40 tahun, sementara pocket periodontal paling banyak ditemukan pada usia 50-60 tahun. ${ }^{2}$

Periodontitis kronis terjadi dimulai dengan pembentukan biofilm dari mikroba terutama golongan gram negatif yang mempengaruhi jaringan gigi sehingga menimbulkan respon tubuh yang menyebabkan kerusakan tulang dan jaringan lunak. Endotoksin yang dihasilkan bakteri menyebabkan aktifnya mediator osteoklast sehingga terjadi proses penghancuran tulang dan ligamen periodontal. Bakteri gram negatif yang dimaksud diantaranya Porphyromonas gingivalis dan A. Actinomycetemcomitans. ${ }^{3}$

Periodontitis agresif adalah penyakit periodontal yang berjalan cepat ditandai dengan hilangnya tulang alveolar secara agresif, penyakit ini tampa didahului dengan keluhan, tidak berhubungan dengan faktor lokal. ${ }^{4}$ Periodontitis agresif banyak diderita oleh usia muda samapi dewasa muda sekita usia 12-18 tahun, dan jarang pada usia dewasa., Periodontitis agresif adalah penyakit multifaktorial, penyebabkanya dapat disebabkan oleh banyak hal seperti reaksi hipersensitif dari reaksi imun tubuh, genetik, faktor lingkungan. ${ }^{6}$ Periodontitis agresif disebabkan adanya gangguan dari bakteri Porphyromonas gingivalis, Actinomycetem Comitans, dan Tannerella forsythia. ${ }^{78}$ Temuan terbaru menunjukkan bahwa patogenesis periodontitis agresif lokal sangat berkaitan dengan fungsi neutrophil yang kemudian menghasilkan kerusakan jaringan yang dimediasi neutrophil. ${ }^{9}$ Kelainan ini terlihat sebagai hasil dari tahap hiperaktif kronis neutrophil. ${ }^{10,11}$

Beberapa penelitian menunjukkan bahwa kelainan neutrofil ini berupa pensinyalan yang menyebabkan intake kalsium berkurang dan berakhir dengan kerusakan jaringan tulang serta membran periodontal. ${ }^{12}$ Kehadiran dan kerusakan pada kedua penyakit ini dapat dilihat salah satunya dengan menggunakan modality radiograf. Radiografi merupakan ilmu yang mempelajari teknis penghasilan radiograf dengan pemanfaatan $\mathrm{x}$-ray, radiograf membantu dalam penentuan diagnosis penyakit. Radiograf mampu menampilkan gambaran kerusakan tulang alveolar meliputi luas dan bentuk, hilang atau adanya pelebaran membran periodontal, serta perubahan pola trabekula. lebar ruang periodontal, dan trabekulasi. ${ }^{4,13}$ Saat ini, peralatan radiografi telah banyak berkembang dan Cone Beam Computed Tomography (CBCT) merupakan salah satu diantaranya. CBCT mampu memberikan gambaran objek dalam $3 \mathrm{D}$ dengan tiga potongan yaitu sagital, aksial, dan koronal. Artikel ini bertujuan untuk mengambarkan karakteristik kerusakan tulang pada penyakit periodontitis agresif dan periodontitis kronis melalui CBCT.

\section{METODE}

Penelitian ini merupakan penelitian deskriptif dimana data diperoleh dari data radiograf CBCT pasien periodontitis kronis dan agresif. Sampel berupa potongan tulang alveolar dari radiograf CBCT

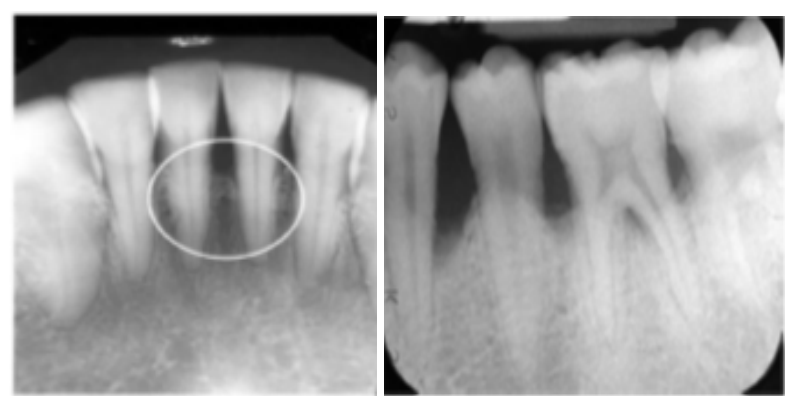

Gambar 1. Gambaran dari kerusakan tulang dari radiograf dua dimensi. Kiri : menunjukan resorpsi horizontal, kanan : menunjukkan resorpsi vertikal. ${ }^{13}$

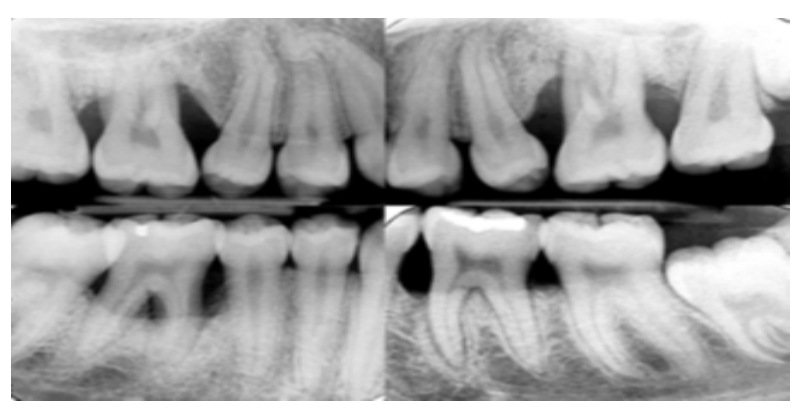

Gambar 2. Gambaran dari kerusakan tulang berbentuk arch shaped dari gambaran dua dimensi. ${ }^{13}$ 

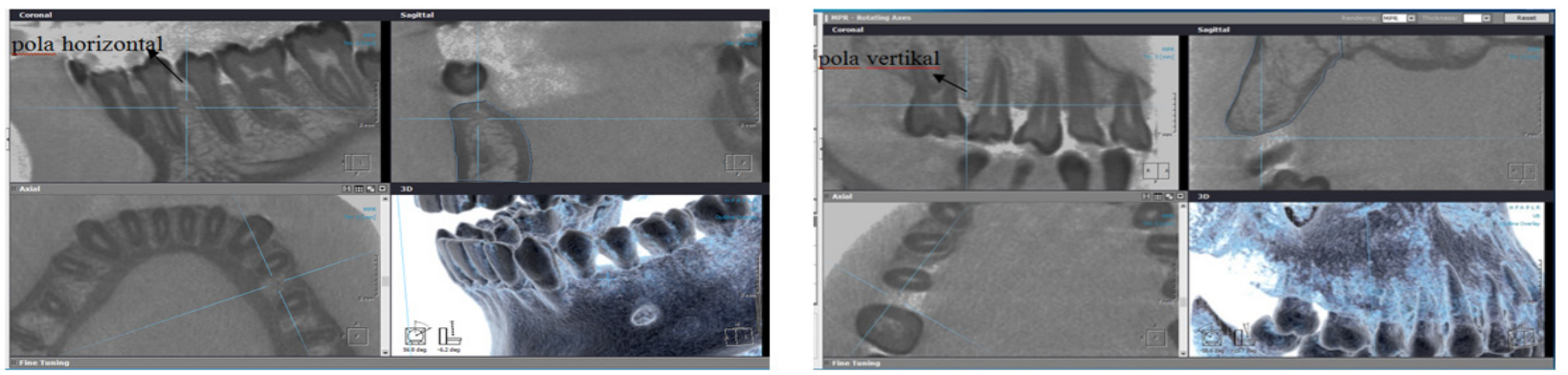

Gambar 3. Merupakan gambaran dari kerusakan tulang dari radiograf CBCT. Kiri : menunjukan pola resorpsi horizontal, kanan : menunjukkan pola resorpsi vertikal. ${ }^{14}$

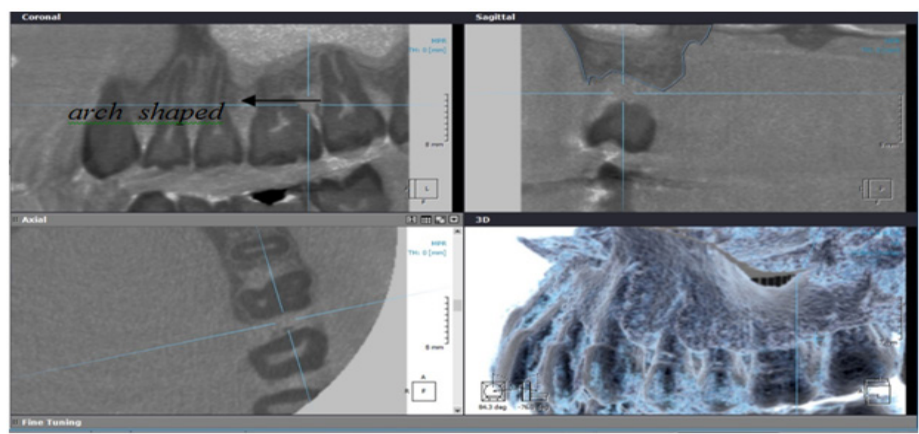

Gambar 4. Merupakan gambaran dari kerusakan tulang berbentuk arch shaped dari gambran CBCT. ${ }^{14}$

dalam populasi. Sampel yang terkumpul berjumlah setiap penyakit berjumlah 107 potongan tulang alveolar.

Metode pengukuran yang dilakukan berupa melihat bentuk pola resorpsi tulang pada potongan sagital dan koronal dengan kriteria bentuk kerusakan tulang horizontal, vertikal dan arch shaped (Gambar 1-4).

\section{HASIL}

Penelitian ini menghasilkan penelitian, karakteristik dari kerusakan tulang alveolar dari dua kelainan periodontitis kronis dan periodontitis agresif, terlihat sebagai berikut:

Tabel 1. Jumlah dan persentase pola kerusakan tulang alveolar dilihat dari arah koronal (coronal view)

\begin{tabular}{ccccc}
\hline $\begin{array}{c}\text { Pola } \\
\text { kerusakan }\end{array}$ & \multicolumn{2}{c}{ Periodontitis agresif } & Periodontitis kronis \\
\hline $\begin{array}{c}\text { Tulang } \\
\text { alveolar }\end{array}$ & Jumlah & Persentase & Jumlah & Persentase \\
\hline Vertikal & 49 & $30,4 \%$ & 33 & $31 \%$ \\
Horizontal & 43 & $26,7 \%$ & 74 & $69 \%$ \\
Arch shaped* & 69 & $48,9 \%$ & 0 & $0 \%$ \\
\hline Total & $\mathbf{1 6 1}$ & $\mathbf{1 0 0 \%}$ & $\mathbf{1 0 7}$ & $\mathbf{1 0 0 \%}$ \\
\hline
\end{tabular}

Tabel 1. menunjukkan pola kerusakan tulang alveolar arah koronal penderita periodontitis agresif terdapat pola kerusakan arch shaped memiliki persentase tertinggi yaitu sebesar 48,9\%, pola kerusakan tulang vertikal sebesar 30,4\%, sedangkan pola kerusakan horizontal sebesar $26,7 \%$. Penderita periodontitis kronis tampak bahwa pola kerusakan tulang horizontal memiliki nilai paling tinggi dengan persentase sebesar $69 \%$, sedangkan pola kerusakan tulang vertikal sebesar $31 \%$ dan pola kerusakan arch shaped sebesar $0 \%$.

Tabel 2 menunjukkan pencitraan CBCT 3D dari arah sagital periodontitis agresif menunjukkan pola kerusakan arch shaped memiliki persentase tertinggi yaitu sebesar 48,9\%, pola kerusakan

Tabel 2. Jumlah dan persentase pola kerusakan tulang alveolar dilihat dari arah sagital (sagital view)

\begin{tabular}{ccccc}
\hline $\begin{array}{c}\text { Pola } \\
\text { kerusakan }\end{array}$ & \multicolumn{2}{c}{ Periodontitis agresif } & Periodontitis kronis \\
\hline $\begin{array}{c}\text { Tulang } \\
\text { alveolar }\end{array}$ & Jumlah & Persentase & Jumlah & Persentase \\
\hline Vertikal & 49 & $30,4 \%$ & 33 & $31 \%$ \\
Horizontal & 43 & $26,7 \%$ & 74 & $69 \%$ \\
Arch Shaped* & 69 & $48,9 \%$ & 0 & $0 \%$ \\
\hline Total & $\mathbf{1 6 1}$ & $\mathbf{1 0 0 \%}$ & $\mathbf{1 0 7}$ & $\mathbf{1 0 0} \%$ \\
\hline
\end{tabular}


tulang vertikal memiliki persentase sebesar $29,8 \%$, sedangkan pola kerusakan horizontal sebesar 27,3\%, sedangkan pada penderita periodontitis kronis tampak bahwa pola kerusakan tulang horizontal memiliki persentase tertinggi yaitu sebesar $65 \%$, pola kerusakan tulang vertikal sebesar 35\% dan tidak terdapat pola kerusakan arch shaped.

\section{PEMBAHASAN}

CBCT 3D merupakan teknik radiografi yang memanfaatkan sinar-x berbentuk kerucut dan rekonstruksi volumetrik komputerisasi yang menghasilkan radiograf tiga dimensi yaitu sagital, aksial, dan koronal. ${ }^{13}$ CBCT memiliki beberapa kelebihan bila dibandingkan dengan alat konvensional dua dimensi, seperti kemampuannya dalam mengamati struktur jaringan tulang karena resolusi dan kontrasnya yang tinggi serta dapat juga membedakan densitas jaringan. ${ }^{14}$

Resorpsi tulang merupakan sebuah istilah dimana terjadi perpindaham meteri jaringan tulang yang lebih dikenal dengan remodeling tulang. Dalam Dalam keadaan normal, terdapat keseimbangan antara dua proses remodeling yaitu resorpsi dan aposisi. Pada saat infeksi proses resorpsi tulang atau penghancuran tulang lebih cepat atau lebih banyak terjadi dibandingkan proses aposisi atau pembentukan tulang, Kondisi mengakibatkan tulang akan tampak rusak. ${ }^{15}$ Peridontitis agresif merupakan penyakit infeksi pada jaringan periodontal yang dimulai pada usia anak-anak sampai dewasa muda yang secara umum tampak sehat, tetapi kerusakan jaringan periodontal termasuk tulang alveolar berlangsung cepat dan cenderung parah. ${ }^{4}$ Gambaran radiografi dua dimensi dari PAL menggambarkan adanya pola kerusakan tulang berbentuk vertikal dan pola khusus yang dikenal dengan nama arch shaped.

Hasil penelitian yang dilakukan dengan pencitraan CBCT menunjukkan bahwa pada periodontitis agresif terjadi kerusakan tulang, dimana bentuk kerusakan didominasi oleh arch shaped, baik dari arah koronal maupun sagital. Secara histopatologi dan imunopatologinya tidak ada perbedaan antara periodontitis agresif dan kronis. ${ }^{16,17}$ Keduanya muncul sebagai kerusakan yang diawali oleh inflamasi dan hadirnya sel plasma. Periodontitis agresif lokal sangat berhubungan dengan daya tahan tubuh berkaitan dengan neutrofil, dan hal ini sangat bersifat genetik/diturunkan. Di sisi lain, periodontitis agresif generalisata sangat dipengaruhi oleh kondisi periodontitis kronis yang terkadang telah diderita sejak anak-anak. ${ }^{18}$ Periodontitis agresif lokal sering kali sangat berhubungan dengan defisiensi dari fungsi neutrofilik dan respons antibodi terhadap perio patogen. ${ }^{19}$ Periodontitis agresif lokalisata disebabkan utama oleh Aggregatibacter actinomycetemcomitans, sedangkan periodontitis agresif generalita lebih banyak disebabkan oleh Porphyromonas gingivalis dan Tannerella forsythia, juga Aggregatibacter actinomycetemcomitans dan Gram-negative coccobill microaerophilic. ${ }^{20-24}$

Etiologi utama pada periodontitis kronis terjadinya resorpsi tulang yaitu adanya akumulasi plak pada gigi serta pada permukaan gusi. Keadaan tersebut sesuai dengan data hasil pemeriksaan kebersihan mulut yang telah dilakukan yaitu dari keempat penderita periodontitis kronis, semuanya memiliki kebersihan mulut yang buruk. Mikroorganisme pada plak yang dapat menginvasi ke jaringan periodontal dan menyebabkan inflamasi dengan mengeluarkan toksin, enzim atau antigen. Keberadaan bakteri spesies tertentu pada plak subgingiva seperti Porphyromonas gingivalis dan A.Actinomycetemcomitans dapat memicu terjadinya penyakit periodontal serta berperan penting dalam pembentukan poket dan destruksi tulang alveolar. ${ }^{16}$

Invasi bakteri atau produk bakteri ke jaringan periodontal menimbulkan berbagai reaksi peradangan dan respon imun. Bahan penting yang berperan sebagai mediator respon imun tubuh adalah sitokin. Beberapa jenis sitokin yang berperan dalam resorpsi tulang yaitu IL-I, IL-6, dan TNF.26 IL-I adalah sitokin yang dihasilkan oleh makrofag dan sel jaringan ikat, berperan penting dalam patogenesis berbagai peradangan kronis, reaksi imun, dan kerusakan jaringan, sitokin ini dapat menyebabkan resorpsi tulang dengan menghambat pembentukan tulang dan meningkatkan jumlah osteoklas. ${ }^{27}$ IL-6 diaktifkan oleh IL-I dan mempunyai peranan sama dengan IL-I dalam menimbulkan kerusakan jaringan periodontal dan tulang alveolar. ${ }^{26,27}$

Pola kerusakan tulang pada periodontitis kronis yang umum terjadi yaitu pola horizontal. Pola ini terjadi ketika kehilangan perlekatan dan tulang alveolar terjadi dengan kecepatan yang sama rata pada sebagian besar permukaan gigi. Berdasarkan hasil pencitraan CBCT, selain pola kerusakan tulang horizontal terdapat juga pola vertikal. Keadaan ini berhubungan dengan faktor risiko yang dapat 
mengubah pola kerusakan tulang alveolar pada periodontitis kronis seperti keadaan sistemik, kondisi emosional, kebiasaan merokok, bruxism, malposisi gigi dan trauma oklusi. Berdasarkan data kuisioner dan pemeriksaan klinis dari 4 penderita periodontitis kronis yang diambil gambaran radiografnya, tidak ada subjek yang memiliki keadaan sistemik, tetapi beberapa pasien mengaku memiliki kebiasaan merokok, pernah mengalami kecelakaan pada region anterior maksila, serta terlihat adanya maloklusi pada region anterior, keadaan ini tampak dari gambaran radiografis pada daerah tersebut yang memiliki pola vertikal.

\section{SIMPULAN}

Karakteristik kerusakan tulang alveolar melalui CBCT, pada periodontitis kronis berupa pola resorpsi harizontal, sedangkan pada periodontitis agresif didominasi oleh kerusakan tulang berbentuk arch shaped.

\section{DAFTAR PUSTAKA}

1. Shaddox LM, Walker CB. Treating chronic periodontitis: current status, challenges, and future directions. Clinical, Cosmetic and Investigational Dentistry. 2010;2:79-91.

2. Heitz-Mayfield LJ, Schatzle M, Loe H, Bürgin W, Anerud A, Boysen $\mathrm{H}$, et al. Clinical course of chronic periodontitis. II. Incidence, characteristics and time of occurrence of the initial periodontal lesion. J Clin Periodontol 2003:30(10):902-8. DOI:10.1034/j.1600051X.

3. Eberhard J, Jepsen S, Jervøe-Storm PM, Needleman I, Worthington HV. Full-mouth treatment modalities (within 24 hours) for chronic periodontitis in adults. Cochrane Database Syst Rev. 2015 Apr 17;(4):CD004622. DOI:10.1002/14651858.CD004622.

4. Carranza FA, Newman MG, Takei HH, Klokkevold PR. Carranza's clinical periodontology. $11^{\text {th }}$ ed. St. Louis: Saunders Elsevier. 2012.

5. Armitage GC, Cullinan MP. Comparison of the clinical features of chronic and aggressive periodontitis. Periodontol 2010: 53(1):12-27.

6. Meng H, Xu L, Li Q Han J, Zhao Y. Determinants of host susceptibility in aggressive periodontitis. Periodontol 2007;43(1):133-59.

7. Carvalho RP, Mesquita JS, Bonomo A, Elsas
PX, Colombo AP. Relationship of neutrophil phagocytosis and oxidative burst with the subgingival microbiota of generalized aggressive periodontitis. Oral Microbiol Immunol 2009;24 (2):124-132.

8. Fine DH, Markowitz K, Furgang D, Fairlie K, Ferrandiz J, Nasri C, McKieran M, Gunsolley J. Aggregatibacter actinomycetemcomitans and its relationship to Initiation of localized aggressive periodontitis: Longitudinal cohort study of initially healthy adolescents. J Clin Microbiol 2007;45(12):3859-69.

9. Kantarci A, Oyaizu K, Van Dyke TE. Neutrophilmediated tissue injury in periodontal disease pathogenesis: Findings from localized aggressive periodontitis. J Periodontol 2003;74(1):66-75.

10. Srinivas M, Chethana KC, Padma R, Suragimath G, Anil M, Pai BS. Walvekar A. A study to assess and compare the peripheral blood neutrophil chemotaxis in smokers and non smokers with healthy periodontium, gingivitis, and chronic periodontitis. J Indian Soc Periodontol. 2012 Jan-Mar;16(1):5458. DOI: $\quad$ 10.4103/0972124X.94605.

11. Barbieri Petrelli G, Flores Guillén J, Vignoletti F. El neutrófilo y su importancia en l enfermedad periodontal. Av Periodon Implantol 2005;17(1):11-6.

12. Shibata K, Warbington ML, Gordon BJ, Kurihara H, Van Dyke TE. Defective calcium influx factor activity in neutrophils from patients with localized juvenile periodontitis. J Periodontol 2000;71(5):797-802.

13. White SC, Pharoah, Michael J. Oral Radiology. $7^{\text {th }}$ ed. St.Louis, Toronto, London: C.V. Mosby Co. 2014. h. 175-90.

14. Rumah Sakit Gigi dan Mulut. CBCT. Bandung: Unpad. 2010.

15. Ibsen OAC, Phelan JA, Ibsen OAC. Oral pathology for the dental hygienist $6^{\text {th }}$ ed. St. Louis Missouri: Elsevier. 2014. h. 116-7.

16. Botero JE, Bedoya E. Determinantes del diagnóstico periodontal. Rev. Clin. Periodoncia Implantol Rehabil Oral 2010;3(2):94-9.

17. Armitage GC, Cullinan MP. Comparison of the clinical features of chronic and aggressive periodontitis. Periodontol 2000. 2010;53(1):1227. DOI: $10.1111 / \mathrm{j} .1600-0757.2010 .00353 . x$.

18. Smith M, Seymour GJ, Cullinan MP. 
Histopathological features of chronic and aggressive periodontitis. Periodontology 2000;53(1):45-54.

19. Discepoli N, Bascones-Martínez A. Controversias etiológicas, diagnósticas y terapéuticas de la periodontitis agresiva. Av. Periodon Implantol 2008;20 (1):39-47.

20. Faveri M, Figueiredo LS, Duarte PM, Mestnik MJ, Mayer MP, Feres M. 2009. Microbiological profile of untreated subjects with localized aggressive periodontitis. J Clin Periodontol 2009;36(9):73949. DOI: 10.1111/j.1600-051X.2009.01449.X.

21. Cortelli JR, Cortelli SC, Jordan S, Haraszthy VI, Zambon JJ. Prevalence of periodontal pathogens in Brazilians with aggressive or chronic periodontitis. J Clin Periodontol 2005;32(8):8606.

22. Könönen E, Müller HP. Microbiology of aggressive periodontitis. Periodontol 2014;65(1):46-78. DOI: $10.1111 /$ prd. 12016.

23. Souza Silveira VR, Bessa Nogueira MV, Pinto Nogueira NA, Lima V, Chaves Furlaneto FA, Otavio Rego R. Leukotoxicity of Aggregatibacter actinomycetemcomitans in generalized aggressive periodontitis in Brazilians and their family members. J Applied Oral Science 2013;21(5):430-6.

24. Fine DH, Kaplan JB, Kachlany SC, Schreiner HC. How we got attached to Actinobacillus actinomycetemcomitans: a model for infectious diseases. Periodontol 2006;42(1):114-57.

25. Stabholz A, Soskolne WA, Shapira L. Genetic and environmental risk factors for chronic periodontitis and aggressive periodontitis. Periodontology 2010;53(1):138-53.

26. Lourenço TG, Heller D, do Souto RM, SilvaSenem MX, Varela VM, Torres MC, Colombo AP. 2015. Long-term evaluation of the antimicrobial susceptibility and microbial profile of subgingival biofilms in individuals with aggressive periodontitis. Braz J Microbiol; 2015;46(2):493500. DOI:10.1590/S1517-838246220131037.

27. Bueno LC, Mayer MP, DiRienzo JM. Relationship between conversion of localized juvenile periodontitis-susceptible children from health to disease and Actinobacillus actinomycetemcomitans leukotoxin promoter structure. J Periodontol 1998:69(9):998-1007. 